\title{
EGFR Inhibition in the Treatment of Non-Small Cell Lung Cancer
}

\author{
David E. Gerber* \\ Department of Internal Medicine, Division of Hematology-Oncology, University of Texas \\ Southwestern Medical Center, Dallas, TX 75390-8852
}

\section{Abstract}

\begin{abstract}
Epidermal growth factor receptor (EGFR) inhibitors have introduced the concept of targeted therapy to the treatment of non-small cell lung cancer (NSCLC). These agents appear most effective in patients with tumors that are highly dependent on EGFR signaling pathways, a population that disproportionately includes females, nonsmokers, individuals of East Asian origin, and patients with adenocarcinoma histology. Currently available EGFR-inhibiting drugs include the tyrosine kinase inhibitors (TKIs) erlotinib, gefitinib, and lapatinib, which are administered orally and interfere with the intracellular tyrosine kinase domain, and the monoclonal antibodies (mAbs) cetuximab and panitumumab, which are administered intravenously and interfere with extracellular ligand binding. While the use of EGFR TKIs as monotherapy prolongs survival in metastatic NSCLC, they have demonstrated no benefit when added to conventional, cytotoxic chemotherapy. In contrast, the antiEGFR mAb cetuximab appears most effective when combined with chemotherapy or radiation. Despite dramatic initial responses to treatment in some cases, NSCLC eventually becomes resistant to EGFR inhibition. Possible mechanisms include secondary mutations that interfere with drug binding, oncogenic pathways driven by other receptor tyrosine kinases, and independent activity of downstream signaling molecules. Efforts to overcome such resistance include irreversibly binding EGFR TKIs, multi-targeted TKIs, and combinations with chemotherapy, radiation, and other targeted therapies.
\end{abstract}

\section{Keywords}

non-small cell lung cancer; epidermal growth factor receptor; monoclonal antibodies; tyrosine kinase inhibitors; targeted therapy

\section{INTRODUCTION}

To understand the impact of epidermal growth factor receptor (EGFR) inhibition on the treatment of non-small cell lung cancer (NSCLC), one must consider the state of NSCLC at the close of the twentieth century. While declining tobacco use in the United States had led to a plateau in new cases, rising smoking rates in developing countries were fueling an increased incidence worldwide. The effectiveness of radiographic screening for lung cancer remained disputed [Henschke et al., 2006]. Almost 75\% of patients presented with advanced, inoperable disease. With standard first-line platinum-based chemotherapy, response rates were approximately 20\%; median survival, approximately 9 months [Schiller et al., 2002]. Secondline treatment regimens, incorporating drugs such as the antimetabolite pemetrexed or the microtubule inhibitor docetaxel, yielded significant toxicity but response rates under $10 \%$ 
[Shepherd et al., 2000]. Third-line chemotherapy, when employed, led to responses in about $2 \%$ of patients [Massarelli et al., 2003]. Lung cancer remained the number one cancer killer in both men and women.

While the treatment of advanced lung cancer has progressed relatively little, the treatment of other malignancies had benefited from recent biologic insights. Imatinib, an inhibitor of the fusion protein BCR-ABL, revolutionized the treatment of chronic myelogenous leukemia [Kantarjian et al., 2002]. Rituximab, an antibody directed against the B-cell marker CD20, significantly improved outcomes when added to standard chemotherapy for the treatment of B-cell non-Hodgkin's lymphoma [Coiffier et al., 2002]. These targeted therapies proved not only effective, but also better tolerated than traditional cytotoxic chemotherapy.

EGFR inhibition has introduced targeted therapy to the treatment of NSCLC. In so doing, it has raised new issues of patient selection and clinical trial design, impacted the assessment of drug efficacy, and expanded the patient population eligible for anti-cancer therapy.

Additionally, the growing understanding of EGFR tyrosine kinase mutations, which appear unique to NSCLC, has highlighted the clinical importance of tumor molecular characteristics in this era of new cancer treatments. To offer insight into the use of EGFR inhibition for NSCLC treatment, this paper reviews EGFR biology, classes of EGFR inhibiting drugs, molecular predictors of EGFR efficacy, clinical trials of EGFR inhibitors, and mechanisms of tumor resistance to EGFR.

\section{EGFR BIOLOGY}

EGFR, also known as HER1 (human epidermal growth factor receptor 1) or ErbB1, belongs to a 4-member family of receptor tyrosine kinases. EGFR has an extracellular ligand-binding domain (621 amino acids), a transmembrane anchoring region (23 amino acids), and an intracellular tyrosine kinase (542 amino acids). After binding of ligand such as epidermal growth factor [EGF], transforming growth factor [TGF], and others), receptor subunits dimerize, which leads to autophosphorylation of intracellular tyrosine residues (see Figure 1). This action creates docking sites for numerous intracellular effector proteins, thereby generating multiple signal transduction cascades. These include the Ras-Raf-MEK (mitogenactivated and extracellular-signal regulated kinase kinase), PI3K (phosphatidylinositol-3 kinase)-Akt, and STAT (signal transducer and activator of transcription) pathways (see Fig. 1). Ultimately, these molecular signals result in cellular proliferation, resistance to apoptosis, cellular invasion, metastasis, and angiogenesis [Schreiber et al., 1986;Petit et al., 1997;Gibson et al., 1999;Modjtahedi et al., 2000;Harari et al., 2007]. Independent of kinase-dependent signal-transduction pathways, the EGFR complex may also be internalized and translocate to the nucleus, where it modifies gene transcription and contributes to DNA repair mechanisms [Lin et al., 2001;Dittmann et al., 2005].

EGFR is present on normal epithelial cells and a variety of cancer cells. EGFR protein overexpression or EGFR gene amplification, mutation, or rearrangement have been demonstrated in multiple malignancies, including cancers of the head and neck, ovary, cervix, bladder, prostate, ovary, esophagus, stomach, brain, breast, endometrium, colon, and lung [Salomon et al., 1995; Krause and Van Etten, 2005]. EGFR is detectable in up to 90\% of cases of NSCLC [Rusch et al., 1993; Dutu et al., 2005]. EGFR expression frequently conveys a more aggressive phenotype and worse prognosis. This association has been demonstrated in bladder, breast, and head and neck cancers, as well as NSCLC [Rubin Grandis et al., 1998; Nicholson, Gee et al., 2001; Ohsaki et al., 2000; Hirsch et al., 2003]. 


\section{EGFR-INHIBITING DRUGS: TYROSINE KINASE INHIBITORS AND MONOCLONAL ANTIBODIES}

The two primary means of inhibiting the EGFR pathway are small molecule tyrosine kinase inhibitors (TKIs) and monoclonal antibodies (mAbs). EGFR TKIs (molecular weight 400-500 daltons) exert their effects intracellularly. They bind competitively to the adenosine triphosphate pocket of EGFR, inhibiting EGFR autophosphorylation and downstream signal transduction. Anti-EGFR mAbs (molecular weight approximately 150,000 daltons) act extracellularly, antagonizing ligand-receptor binding. This, in turn, prevents receptor subunit dimerization, EGFR autophosphorylation, and signal transduction. Both EGFR TKIs and antiEGFR mAbs may provide a predominantly cytostatic effect, requiring researchers and clinicians to consider tumor stabilization, in addition to tumor shrinkage, when assessing treatment efficacy.

While the overarching biologic effect—inhibition of EGFR signaling —of these two drug classes is similar, a number of functional distinctions may explain some of the clinical differences (see Table 1). In addition to blockade of EGFR signaling, anti-EGFR mAbs lead to receptor internalization, degradation, and long-term down-regulation [Prewett et al., 1996;Mendelsohn, 1997;Lilenbaum, 2006]. This process does not occur with currently approved EGFR TKIs, which bind reversibly. Additionally, anti-EGFR mAbs, particularly those of IgG1 isotype, may recruit host immune functions to attack the targeted cancer cell. These functions include antibody-dependent cellular cytotoxicity (ADCC; namely, tumor cellkilling mononuclear cells such as macrophages and natural killer cells) and, to a lesser extent, complement-dependent cytotoxicity.

Currently, there are five FDA-approved drugs that inhibit EGFR: 3 TKIs (erlotinib [Tarceva, Genentech, South San Francisco, CA/OSI Pharmaceuticals, Melville, NY], gefitinib [Iressa, AstraZeneca, Wilmington, DE], and lapatinib [Tykerb, GlaxoSmithKline, Middlesex, England]) and two mAbs (cetuximab [Erbitux, ImClone Systems, New York, NY] and panitumumab [Vectibix, Amgen, Thousand Oaks, CA]). Three of these drugs (erlotinib, gefitinib, and cetuximab) have been studied extensively in NSCLC. Erlotinib is indicated for second- or third-line monotherapy for metastatic NSCLC. In the United States, gefitinib is indicated only for NSCLC patients who have previously benefited from gefitinib treatment or in the context of a clinical trial. The FDA retracted its general approval for this drug when a phase III trial failed to demonstrate an overall survival benefit [Thatcher et al., 2005]. Lapatinib is a dual HER1 (EGFR) and HER2/neu inhibitor, and is indicated for the treatment of HER2positive breast cancer. Cetuximab is a chimeric ( $2 / 3$ human protein, $1 / 3$ mouse protein) IgG1 $\mathrm{mAb}$. The presence of mouse protein leads to possible acute infusion reactions (hence antihistamine premedication is required) and the generation of human anti-mouse antibodies, which could neutralize the effect of the exogenous, therapeutic antibody. Cetuximab is currently approved for the treatment of colorectal and head and neck cancers. It has also been studied extensively in NSCLC.

Panitumumab is a human (100\% human protein) $\operatorname{IgG} 2 \mathrm{mAb}$ approved for the treatment of advanced colorectal cancer. Because of its fully human construct, it is less likely to cause allergic infusion reactions than cetuximab. Its IgG2 isotype makes interaction with host immune functions, such as ADCC, less likely than might occur with an IgG1 mAb. Generally, EGFR-inhibiting drugs are well tolerated, with acneiform rash and diarrhea the primary toxicities of both TKIs and mAbs. Rare cases of interstitial lung disease have also been reported [Inoue et al., 2003]. Significant hypomagenesemia occurs in approximately $10 \%$ of patients treated with cetuximab monotherapy [Jonker et al., 2007] and in more than 50\% of patients receiving cetuximab plus platinum-based chemotherapy [Butts et al., 2007]. 


\section{IDENTIFICATION OF THE TARGET POPULATION}

An underlying premise of targeted therapy is the identification of a target population. For instance, the use of the hormone receptor tamoxifen is limited to the two-thirds of patients with breast cancer whose tumors express the estrogen receptor and/or the progesterone receptor [Early Breast Cancer Trialists' Collaborative Group, 1998]. Estrogen receptor and progesterone receptor status can be determined using standard immunohistochemistry (IHC) techniques. Imatinib (Gleevec) is an inhibitor of the tyrosine kinase of the fusion protein BCR-ABL (breakpoint cluster region Abelson) and is used in the treatment of chronic myelogenous leukemia. Prior to treatment, the presence of BCR-ABL can be inferred through the detection of the Philadelphia chromosome (t9;22), either through cytogenetic analysis (i.e., karyotype), fluorescence in situ hybridization (FISH), or polymerase chain reaction (PCR). In contrast to the relatively straightforward identification of patients likely to benefit from tamoxifen or imatinib, the selection of patients likely to benefit from EGFR-inhibiting drugs remains a complex and disputed process.

\section{Predicting Response to EGFR TKIs: EGFR Mutations, Amplification, and Gene copy number}

In early studies of EGFR TKIs, the level of EGFR protein expression in tumor tissue did not appear to correlate with treatment response [Perez-Soler et al., 2004]. Instead, multiple clinical investigators noted that patients most likely to respond to these drugs were females, those with minimal or no smoking history, those of East Asian descent, and those with adenocarcinoma histology (particularly those with bronchioloalveolar features) [Fukuoka et al., 2003; Kris et al., 2003; Janne et al., 2004; Perez-Soler et al., 2004; Kim et al., 2005; Veronese et al., 2005]. Molecular analysis of tumor specimens from these individuals revealed high rates of activating mutations in the EGFR tyrosine kinase domain (centered around exons 18-21) [Kosaka et al., 2004; Lynch et al., 2004; Paez et al., 2004; Pao et al., 2004, 2005a,b; Kobayashi et al., 2005; Kwak et al., 2005]. These mutations hyperactivate the EGFR tyrosine kinase, rendering cancer cells highly dependent on EGFR oncogenic pathways for survival (a concept known as oncogene addiction) [Weinstein, 2002; Weinstein and Joe, 2006; Sharma et al., 2007] and thus exquisitely sensitive to EGFR inhibition.

Exon 19 and exon 21 mutations each account for approximately $45 \%$ of $E G F R$ gene mutations. Exon 19 mutations, most commonly in-frame deletions of amino acids 747-750, are clustered around the catalytic domain and flank the ATP-binding site. In addition to activating EGFR TK signaling, these structural changes enhance drug binding, resulting in complete blockade of mutated EGFR signaling at relatively low TKI doses [Yun et al., 2007]. Exon 21 mutations, which lie within the TK activation loop, are characteristically L858R substitutions. The remaining 10\% of EGFR TK mutations, in exons 18 and 20, do not confer sensitivity to EGFR TKIs and in some cases are associated with resistance (see the section, Resistance to EGFR Inhibition, below).

In NSCLC cases featuring EGFR gene mutations, EGFR TKIs have radiographic response rates of over $60 \%$, compared with response rates of approximately $10 \%$ in wild-type cases [Bell et al., 2005; Cappuzzo et al., 2005; Han et al., 2005; Mitsudomi et al., 2005; Takano et al., 2005; Sequist et al., 2007; Sequist and Lynch, 2008]. Higher response rates have translated into longer median survival (up to 30 months in some studies) [Cappuzzo et al., 2005; Han et al., 2005; Mitsudomi et al., 2005]. Nevertheless, EGFR mutation status has limited applicability in North America and Western Europe, where only 10\% of NSCLC cases have EGFR gene mutations, compared with 30-50\% of cases in East Asia [Kosaka et al., 2004; Cappuzzo et al., 2005; Chou et al., 2005; Han et al., 2005; Janne et al., 2005; Marchetti, et al., 2005; Mitsudomi, Kosaka et al., 2005; Shigematsu et al., 2005; Tsao et al., 2005; Haneda et al., 2006]. 
Given this limitation, several groups have employed EGFR gene amplification and gene copy number to supplement or replace EGFR gene mutation status [Cappuzzo et al., 2005; Hirsch et al., 2005, 2006, 2007; Takano et al., 2005; Tsao et al., 2005; Han et al., 2006; Miller et al., 2008]. In a cohort of Italian patients with NSCLC, Cappuzzo and colleagues used FISH to determine gene amplification (tight gene clusters; or a ratio of EGFR gene-to-chromosome $\geq 2$ or $\geq 15$ gene copies per cell) and/or chromosome polysomy ( $\geq 4$ chromosomes in $\geq 40 \%$ of cells) [Cappuzzo et al., 2005]. In the study, 33\% of cases were FISH-positive, compared to a $17 \%$ rate of EGFR gene mutations. FISH positivity was associated with higher radiographic response rates ( $36 \%$ vs $3 \%$ for FISH-negative; $P<0.001$ ) and longer median survival (18.7 months vs 7.0 months for FISH-negative; $P=0.03$ ). Whether $E G F R$ gene mutation status or $E G F R$ gene copy number is the optimal means to predict treatment outcomes remains a controversial and debated issue in NSCLC research. It appears to depend on patient population. Studies performed in predominantly Caucasian patients, in whom EGFR gene mutations occur rarely, tend to favor the use of EGFR gene copy number [Tsao et al., 2005; Cappuzzo et al., 2005]. Studies performed in East Asian countries, where EGFR gene mutations occur more frequently, typically favor the use of EGFR gene mutations [Bell et al., 2005; Takano et al., 2005; Ahn et al., 2008].

\section{Predicting Response to anti-EGFR Monoclonal Antibodies}

In contrast to their impact on EGFR TKI-based therapy, EGFR gene mutations do not appear to predict response to anti-EGFR mAbs [Hanna et al., 2006]. Indeed, preclinical studies of NSCLC harboring EGFR gene mutations have demonstrated responses to gefitinib after failure of cetuximab. This pattern has also been described in clinical case reports [Mukohara et al., 2005; Raez et al., 2005]. In general, clinical trials of cetuximab for NSCLC have required tumor specimens to be positive for EGFR by IHC. Other proposed determinants of tumor sensitivity to anti-EGFR mAbs come primarily from studies of colorectal cancer, where cetuximab has been studied more extensively. These include EGFR gene amplification by FISH [Moroni et al., 2005], polymorphisms in EGFR and Cyclin D1 [Zhang et al., 2006], levels of the EGFR ligands amphiregulin and heregulin [Khambata-Ford et al., 2007], mutations of the protooncogene $K$-ras [Khambata-Ford et al., 2007], and-reflecting the role of ADCC in the antitumor effect of mAbs-polymorphisms of the Fc $\gamma$ receptor on host immune cells [Zhang et al., 2007].

\section{Rash}

The development and severity of an acneiform rash, the primary toxicity of EGFR inhibition, appears to correlate with disease response and survival. In studies of EGFR TKIs and antiEGFR mAbs for multiple cancer types, including NSCLC, pancreatic, and colorectal cancers, patients who developed rash requiring clinical intervention had significantly prolonged survival compared to patients without rash [Perez-Soler et al., 2004; Jonker et al., 2007; Moore et al., 2007; Van Cutsem et al., 2007; Wacker et al., 2007; Rosell et al., 2008]. The rash arises from treatment effects on EGFR in normal epithelium. Treatment includes topical and systemic antibiotics and steroids.

\section{CLINICAL EXPERIENCE WITH EGFR INHIBITING DRUGS FOR NSCLC EGFR TKI Monotherapy}

To date, the only form of EGFR inhibition FDA-approved for the treatment of NSCLC is second- and third-line EGFR TKI monotherapy for metastatic/recurrent disease. In May 2003, the FDA granted accelerated approval to gefitinib based on phase II clinical trials demonstrating response and survival rates comparable to those achieved with second-line cytotoxic chemotherapy [Shepherd et al., 2000; Fukuoka et al., 2003; Kris et al., 2003]. In the Iressa Dose Evaluation in Advanced Lung Cancer 1 (IDEAL 1) trial, an international study 
with multiple sites in East Asia, patients with progressive, advanced lung cancer after one or two prior chemotherapy regimens were randomized to receive gefitinib $250 \mathrm{mg}$ orally daily or $500 \mathrm{mg}$ orally daily. For the two doses, response rate, median progression-free survival, and median overall survival were $18.4 \%$ and 19\%, 2.7 months and 2.8 months, and 7.6 and 8.0 months, respectively [Fukuoka et al., 2003]. In IDEAL 2, a similarly structured study performed in the United States, radiographic responses occurred in $12 \%$ of patients receiving gefitinib $250 \mathrm{mg}$ orally daily, and in $9 \%$ of patients receiving the 500-mg dose. The higher dose was not associated with higher rates of symptom improvement, radiographic tumor regression, or survival, but was associated with significantly higher rates of rash and diarrhea [Kris et al., 2003]. Accordingly, gefitinib $250 \mathrm{mg}$ orally daily was the dose recommended for phase 3 studies.

The subsequent fate of gefitinib provides a lesson in the nuances of clinical trial design. The Iressa Survival Evaluation in Lung Cancer (ISEL) trial, a randomized, double-blind, placebocontrolled phase III study of gefitinib for refractory metastatic NSCLC, enrolled 1,692 patients from 210 centers in 20 countries [Thatcher et al., 2005]. Patients randomized to receive gefitinib had a significantly higher radiographic response rate compared with placebo (8\% vs $1 \%$; $P<0.0001$ ), but did not have significantly longer survival (median overall survival 5.6 vs 5.1 months; $P=0.087)$. Following the negative survival result, gefitinib was relabeled for use restricted to patients already receiving and benefiting from the drug, or patients participating in clinical trials. This essentially removed the drug from the American and European markets, although it remained approved and widely used in Asia. Two phase III studies of gefitinib (one evaluating gefitinib maintenance after concomitant chemoradiation [Kelly et al., 2008]; the other evaluating adjuvant gefitinib after resection of early-stage NSCLC [NCIC BR19]) closed prematurely.

In contrast, following an encouraging single-arm phase II trial [Perez-Soler et al., 2004], a randomized, double-blind, placebo-controlled phase III clinical trial of the EGFR TKI erlotinib (NCIC BR21) demonstrated a statistically significant survival benefit, with median overall survival 6.7 months and 1-year survival $31 \%$ for patients treated with erlotinib, compared to 4.7 months and $22 \%$, respectively, for placebo [Shepherd et al., 2005]. Erlotinib subsequently received FDA approval for second- and third-line treatment of metastatic/recurrent NSCLC. The discrepant results of the ISEL (gefitinib) and BR21 (erlotinib) trials have been attributed to differences in study populations, drug dosing and exposure, and pharmacodynamics (see Table 2) [Blackhall et al., 2006]. Specifically, eligibility criteria for ISEL required patients to have early relapsed disease - potentially selecting for a more aggressive, resistant phenotype - whereas BR21 specified no time frame for relapse. In BR21, erlotinib was administered at its maximum tolerated dose (MTD). In ISEL, the gefitinib dose was below the MTD, and the lower rates of rash and diarrhea in the ISEL trial suggest lower systemic drug exposure in this study.

\section{EGFR TKIs Plus Chemotherapy}

Because cytotoxic chemotherapy has long provided the backbone of therapy for advanced NSCLC, a number of early clinical trials of EGFR TKIs evaluated their use in combination with chemotherapy. Administering EGFR TKIs with conventional chemotherapy is biologically rational. Cellular targets and mechanisms of action differ, so cross-resistance should not arise. EGFR phosphorylation occurs in response to various cytotoxic chemotherapy drugs, rendering cells dependent on EGFR for cell survival and therefore increasingly sensitive to EGFR inhibition [Benhar et al., 2002; Azzariti et al., 2004; Sumitomo et al., 2004; Mendelsohn and Fan, 1997; Nyati et al., 2006]. EGFR TKIs may also inhibit repair of chemotherapy-induced DNA inter-strand crosslinks [Friedmann et al., 2004]. A number of 
animal studies have demonstrated that EGFR TKIs potentiate the effects of cytotoxic chemotherapy [Ciardiello et al., 2000; Sirotnak et al., 2000].

Despite a compelling biologic rationale and encouraging preclinical data, four large randomized phase III trials of chemotherapy with or without an EGFR TKI in patients with advanced-stage NSCLC (altogether totaling over 4,000 patients) did not demonstrate an improvement in clinical outcomes with combination therapy (see Table 3) [Giaccone et al., 2004;Herbst et al., 2004,2005;Gandara et al., 2007]. One explanation for these results is that patients were not selected based on molecular predictors. A study population enriched for EGFR gene mutation or amplification might have benefited, but the significance of these biomarkers was not known at the time these studies were initiated. However, it must also be noted that the in the pivotal phase III clinical trial of single-agent erlotinib, all categories of patients with advanced NSCLC derived survival benefit, including those otherwise expected to have low rates of biomarker positivity, such as men with extensive smoking history and squamous cell histology [Shepherd et al., 2005]. Another potential reason is that the cytostatic effect of EGFR TKIs may actually antagonize the effect of chemotherapy [Gandara and Gumerlock, 2005]. EGFR TKIs induce a G1 cell cycle arrest, which could interfere with the cell cycle-specific ( $\mathrm{S}$ and $\mathrm{G} 2 / \mathrm{M}$ phase) cytotoxicity of some chemotherapy drugs [Kimura, 2004;Perez-Soler et al., 2004]. This concern recalls earlier observations of tamoxifen, a hormone receptor modulator that induces G1 arrest. Breast cancer studies of adjuvant chemotherapy plus temoxifen have demonstrated superior outcomes with sequential, rather than concurrent, schedules [Albain, 2002].

To avoid the potential antagonism of EGFR TKIs and chemotherapy, more recent clinical trials of combination therapy have incorporated modified dosing schedules to achieve pharmacodynamic separation [Gandara et al., 2007]. One approach is sequential therapy, in which cytotoxic chemotherapy is administered for several cycles, then discontinued and followed by EGFR TKI therapy. A recent example is the Southwest Oncology Group (SWOG) 0023 phase III clinical trial. In this study patients with inoperable stage III NSCLC received concurrent chemoradiotherapy (cisplatin and etoposide with concurrent thoracic radiation to a total dose of $61 \mathrm{~Gy}$ ), followed by 3 cycles of consolidation chemotherapy with docetaxel, and were then randomized to receive maintenance gefitinib $250 \mathrm{mg}$ daily or placebo [Kelly et al., 2008]. Quite unexpectedly, outcomes were significantly worse among patients receiving EGFR TKI therapy. At a median follow-up of 27 months, median survival was 23 months for patients receiving gefitinib $(\mathrm{n}=118)$ and 35 months for patients receiving placebo $(\mathrm{n}=125)(P=0.013)$. Gefitinib-associated toxicity accounted for $2 \%$ of deaths, and most patients in the gefitinib arm died due to progressive lung cancer. The investigators remarked that these results were unlikely to arise from differences in unmeasured baseline clinical (e.g., smoking status) or molecular characteristics. Instead, they postulated that chemoradiation may alter EGFR biology [Kelly et al., 2008]. Ongoing clinical trials combining chemotherapy and EGFR TKIs are incorporating intermittent dosing [Perez-Soler et al., 2004; Davies, 2005]. In these studies, EGFR TKI treatment is administered in between doses of cytotoxic chemotherapy, thereby minimizing potentially antagonistic cell cycle effects.

\section{EGFR TKIs in Enriched Populations}

To evaluate the use of EGFR TKIs for first-line NSCLC treatment, a number of phase II trials have prospectively screened patients based on molecular and clinical features to define a population most likely to benefit from such therapy (see Table 4). Response rates range from $55 \%$ to $82 \%$ and median progression-free survival ranges $8.9-13.3$ months. These promising results require confirmation in randomized clinical trials, as well as a uniform means to identify the target population. If achieved, such an approach represents a rational approach to the use of targeted therapy in this disease. 


\section{Anti-EGFR mAbs}

In contrast to EGFR TKIs, the anti-EGFR mAb cetuximab appears to provide the greatest benefit when combined with other treatment modalities. Cetuximab produces modest singleagent activity, with radiographic responses in fewer than 5\% of patients [Hanna et al., 2006]. However, the addition of cetuximab to first-line chemotherapy, as studied previously in colorectal and head and neck cancers [Cunningham et al., 2004; Saltz etal.,2004; Burtness et al., 2005] demonstrates promising activity in NSCLC (see Table 5). In particular, the FLEX study, a randomized phase III clinical trial comparing chemotherapy (cisplatin plus vinorelbine) alone to chemotherapy plus cetuximab, has demonstrated a clinically modest though statistically significant overall survival benefit with the addition of cetuximab (OS 11.3 vs 10.1 months; $\mathrm{HR}=0.87 ; 95 \% \mathrm{CI}, 0.76-0.99 ; P=0.04$ ) [Pirker et al., 2008]. Interestingly, progression-free survival was identical in the two arms (4.8 months). In contrast to that of EGFR TKIs, the overall survival benefit was greatest in Caucasian patients $(\mathrm{N}=945)(\mathrm{OS} 11.3$ vs 10.1 months; $\mathrm{HR}=0.80$ [95\% CI, 0.69-0.93]; $P=0.003)$, while Asian patients $(\mathrm{N}=121)$ had a nonsignificant trend toward worse survival with the cetuximab combination (OS 17.6 vs 20.4 months for chemotherapy alone; HR 1.18 [95\% CI, 0.73-1.91]; $P=0.49$ ). How these results will be incorporated into clinical practice, and whether they will lead to FDA approval of cetuximab in combination with chemotherapy for first-line treatment of NSCLC, remains to be seen.

Why might the experience with an anti-EGFR mAb plus chemotherapy seem more encouraging than that with EGFR TKIs plus chemotherapy? As shown in Table 1, mAbs provide pharmacodynamic effects beyond kinase inhibition, including EGFR degradation and longterm down-regulation, activation of ADCC, and suppression of EGFR-associated repair of DNA strand breaks [Lilenbaum, 2006;Chen and Nirodi, 2007]. EGFR TKIs are subject to the variability of oral absorption and cytochrome P-450 metabolism, whereas cetuximab is administered intravenously and has a more predictable pharmacokinetic curve. Additionally, clinical trials of cetuximab have selected patients based on positive EGFR staining in tumor samples [Gatzemeier et al.; Prenzel et al., 2001], although the degree to which EGFR expression predicts benefit from EGFR inhibitors remains controversial [Johnson and Janne, 2005].

\section{RESISTANCE TO EGFR INHIBITION}

\section{Pathogenesis of Resistance}

Although EGFR TKIs and anti-EGFR mAbs provide substantial clinical benefit to some patients with NSCLC, most NSCLC cases are resistant to EGFR inhibition. Even patients achieving dramatic responses to EGFR inhibitors, such as those whose tumors harbor EGFR gene mutations, generally develop resistant disease in 6-12 months [Sharma et al., 2007]. Primary or acquired resistance to EGFR inhibition may arise from specific TK domain mutations, activity of downstream signaling molecules independent of EGFR regulation, or generation of pro-survival signals through alternate molecular pathways [Camp et al., 2005; Kwak et al., 2005; Rubin and Duensing, 2006; Sequist and Lynch, 2008].

A threonine-to-methionine substitution at codon 790 in exon 20 (T790M) of the EGFR gene usually occurs as a secondary mutation in tumors treated with EGFR inhibitors and is thought to account for about half of all cases of acquired TKI resistance [Kosaka et al., 2004; Bell et al., 2005; Kobayashi et al., 2005; Pao et al., 2005; Inukai et al., 2006]. The bulkier methionine amino acid residue leads to a 3-dimensional change in the ATP kinase binding pocket of EGFR, resulting in steric hindrance of EGFR TKI binding [Greulich et al., 2005]. This modification of a "gatekeeper" threonine residue is structurally analogous to mutations in BCR-ABL and PGDFR conferring resistance to imatinib and other kinase inhibitors [Gorre et al., 2001; Blencke et al., 2004; Carter et al., 2005]. 
Activating mutations in codons 12 and 13 of the $K$-ras gene occur in 15-30\% of NSCLC and appear to confer resistance to EGFR TKIs [Rodenhuis et al., 1987; Mitsudomi et al., 1991; Pao et al., 2005]. These mutations lead to constitutive activity of K-ras, a proto-oncogenic intracellular mediator downstream of EGFR (see Fig. 1), independent of EGFR signaling. $K$ ras gene mutations are strongly associated with smoking and almost always occur in the absence of EGFR activating mutations [Husgafvel-Pursiainen et al., 1993; Ahrendt et al., 2001; Sharma et al., 2007; Miller et al., 2008].

Molecular cross-talk and redundancy between EGFR and other signaling pathways creates alternative pathways for tumor cell proliferation, thereby bypassing EGFR and promoting resistance to EGFR inhibition (see Fig. 1). Examples include the receptor tyrosine kinases MET (which binds the ligand hepatocyte growth factor/scatter factor) [Engelman et al., 2007b;Yang et al., 2008], insulin-like growth factor receptor [Chakravarti et al., 2002;Hurbin et al., 2002], and vascular endothelial growth factor receptor (VEGFR) [Byers and Heymach, 2007; Shibuya et al., 2007; Tabernero, 2007].

\section{Approaches to Overcoming Resistance}

The two main strategies employed to overcome resistance to EGFR inhibition are the use of irreversible EGFR inhibitors and the simulatenous blocking of multiple signaling pathways with either a combination of agents or a single multi-targeted drug. In contrast to reversible first-generation EGFR TKIs, irreversible EGFR TKIs bind to EGFR covalently and appear to overcome hindrance to binding T790M mutated EGFR [Discafani et al., 1999; Smaill et al., 2000; Sharma et al., 2007]. In vitro, cancer cells that have acquired resistance to first-generation EGFR TKIs remain sensitive to irreversible EGFR inhibitors [Kwak et al., 2005].

A number of irreversible EGFR TKIs are currently in clinical trials [Erlichman et al., 2006; Sequist, 2007], as are multi-kinase targeted inhibitors. The latter include pan-ErbB (HER1, HER2, HER4) and dual EGFR/VEGFR TKIs [Engelman et al., 2007a; Heymach et al., 2007]. Clinical evidence of the activity of dual EGFR and VEGFR inhibition in NSCLC was demonstrated in a phase I/II trial of the combination of erlotinib plus the anti-VEGF $\mathrm{mAb}$ bevacizumab, which yielded a response rate of $20 \%$ [Herbst et al., 2005]. Among other proposed approaches are combining EGFR inhibitors with PI3K inhibitors [Ihle et al., 2005; Fan et al., 2006], mTOR inhibitors [Easton and Houghton, 2004; Doherty et al., 2006], and Ras-MAPK pathway inhibitors [Adjei, 2006].

\section{CONCLUSIONS AND FUTURE DIRECTIONS}

EGFR inhibitors have markedly changed the management of advanced NSCLC. They have introduced the concept of individualized therapy. Treatment selection may reflect patient ethnicity and gender, as well as tumor histology and molecular characteristics. EGFR inhibitors have also introduced new classes of drugs-TKIs and mAbs-to a disease previously treated with cytotoxic chemotherapy alone. These agents are generally better tolerated than traditional chemotherapy, likely improving patient quality of life. With a median age at diagnosis of 70 years, many NSCLC patients previously considered ineligible for anti-cancer therapy because of comorbidities and frailty may now receive treatment. Most importantly, EGFR inhibitors have provided proof of principle that, for the treatment of NSCLC, disease biology and treatment are inextricably linked.

Yet despite these apparent advances, for most patients with NSCLC, EGFR inhibitors have not dramatically changed clinical outcomes. The molecular complexity of lung cancer underlies these disappointments. In chronic myelogenous leukemia, almost all cases arise from a single genetic defect, a chromosomal translocation resulting in the pathognomonic BCR$\mathrm{ABL}$ fusion protein. Consequently, antagonism of BCR-ABL with the TKI imatinib leads to 
complete hematologic responses in almost all patients [Kantarjian et al., 2002]. In contrast, EGFR is only one of numerous aberrant biologic processes in NSCLC. Its relative importance in disease promotion and progression varies widely among patients. Ongoing research on EGFR inhibition is responding to these factors; it is hoped that it will provide incremental improvements in the outcomes of patients with this challenging disease.

\section{ACKNOWLEDGMENTS}

The author thanks Lara M. Johnson and Joan H. Schiller for their review of the manuscript.

\section{Abbreviations}

ADCC, antibody-dependent cellular cytotoxicity

EGFR, epidermal growth factor receptor

FISH, fluorescence in situ hybridization

HER, human epidermal growth factor receptor

IHC, immunohistochemistry

$\mathrm{mAb}$, monoclonal antibody

NSCLC, non-small cell lung cancer

PCR, polymerase chain reaction

PI3K, phosphatidylinositol-3 kinase

STAT, signal transducer and activator of transcription

TKI, tyrosine kinase inhibitor

VEGFR, vascular endothelial growth factor receptor.

\section{REFERENCES}

Adjei AA. Novel combinations based on epidermal growth factor receptor inhibition. Clin Cancer Res 2006;12(Pt 2):4446s-4450s. [PubMed: 16857826]

Ahn MJ, Park BB, et al. Are there any ethnic differences in molecular predictors of erlotinib efficacy in advanced non-small cell lung cancer? Clin Cancer Res 2008;14:3860-3866. [PubMed: 18559606]

Ahrendt SA, Decker PA, et al. Cigarette smoking is strongly associated with mutation of the K-ras gene in patients with primary adenocarcinoma of the lung. Cancer 2001;92:1525-1530. [PubMed: 11745231]

Albain KG, Green SJ, Ravdin PM, Cobau CD, Levine EG, Ingle JN, Pritchard KI, Schneider DJ, Abeloff MD, Norton L, Henderson IC, Lew D, Livingston RB, Martino S, Osborne CK. Adjuvant chemohormonal therapy for primary breast cancer should be sequential instead of concurrent: initial results from intergroup trial 0100 (SWOG-8814). Proc Am Soc Clin Oncol 2002;21abstract 143

Asahina H, Yamazaki K, et al. A phase II trial of gefitinib as first-line therapy for advanced non-small cell lung cancer with epidermal growth factor receptor mutations. Br J Cancer 2006;95:998-1004. [PubMed: 17047648]

Azzariti A, Xu JM, et al. The schedule-dependent enhanced cytotoxic activity of 7-ethyl-10-hydroxycamptothecin (SN-38) in combination with Gefitinib (Iressa, ZD1839). Biochem Pharmacol 2004;68:135-144. [PubMed: 15183125]

Bell DW, Gore I, et al. Inherited susceptibility to lung cancer may be associated with the T790M drug resistance mutation in EGFR. Nat Genet 2005;37:1315-1316. [PubMed: 16258541]

Bell DW, Lynch TJ, et al. Epidermal growth factor receptor mutations and gene amplification in nonsmall-cell lung cancer: molecular analysis of the IDEAL/INTACT gefitinib trials. J Clin Oncol 2005;23:8081-8092. [PubMed: 16204011]

Benhar M, Engelberg D, et al. Cisplatin-induced activation of the EGF receptor. Oncogene 2002;21:8723-8731. [PubMed: 12483525]

Blackhall F, Ranson M, et al. Where next for gefitinib in patients with lung cancer? Lancet Oncol 2006;7:499-507. [PubMed: 16750500]

Drug Dev Res. Author manuscript; available in PMC 2009 June 25. 
Blencke S, Zech B, et al. Characterization of a conserved structural determinant controlling protein kinase sensitivity to selective inhibitors. Chem Biol 2004;11:691-701. [PubMed: 15157880]

Burtness B, Goldwasser MA, et al. Phase III randomized trial of cisplatin plus placebo compared with cisplatin plus cetuximab in metastatic/recurrent head and neck cancer: an Eastern Cooperative Oncology Group study. J Clin Oncol 2005;23:8646-8654. [PubMed: 16314626]

Butts CA, Bodkin D, et al. Randomized phase II study of gemcitabine plus cisplatin, with or without cetuximab, as first-line therapy for patients with advanced or metastatic non small-cell lung cancer. J Clin Oncol 2007;25:5777-5784. [PubMed: 18089875]

Byers LA, Heymach JV. Dual targeting of the vascular endothelial growth factor and epidermal growth factor receptor pathways: rationale and clinical applications for non-small-cell lung cancer. Clin Lung Cancer 2007;8(Suppl 2):S79-85. [PubMed: 17382029]

Camp ER, Summy J, et al. Molecular mechanisms of resistance to therapies targeting the epidermal growth factor receptor. Clin Cancer Res 2005;11:397-405. [PubMed: 15671571]

Cappuzzo F, Hirsch FR, et al. Epidermal growth factor receptor gene and protein and gefitinib sensitivity in non-small-cell lung cancer. J Natl Cancer Inst 2005;97:643-655. [PubMed: 15870435]

Carter TA, Wodicka LM, et al. Inhibition of drug-resistant mutants of ABL, KIT, and EGF receptor kinases. Proc Natl Acad Sci USA 2005;102:11011-11016. [PubMed: 16046538]

Chakravarti A, Loeffler JS, et al. Insulin-like growth factor receptor I mediates resistance to antiepidermal growth factor receptor therapy in primary human glioblastoma cells through continued activation of phosphoinositide 3-kinase signaling. Cancer Res 2002;62:200-207. [PubMed: $11782378]$

Chen DJ, Nirodi CS. The epidermal growth factor receptor: a role in repair of radiation-induced DNA damage. Clin Cancer Res 2007;13(Pt 1):6555-6560. [PubMed: 18006754]

Chou TY, Chiu CH, et al. Mutation in the tyrosine kinase domain of epidermal growth factor receptor is a predictive and prognostic factor for gefitinib treatment in patients with non-small cell lung cancer. Clin Cancer Res 2005;11:3750-3757. [PubMed: 15897572]

Ciardiello F, Caputo R, et al. Antitumor effect and potentiation of cytotoxic drugs activity in human cancer cells by ZD-1839 (Iressa), an epidermal growth factor receptor-selective tyrosine kinase inhibitor. Clin Cancer Res 2000;6:2053-2063. [PubMed: 10815932]

Coiffier B, Lepage E, et al. CHOP chemotherapy plus rituximab compared with CHOP alone in elderly patients with diffuse large-B-cell lymphoma. NEngl J Med 2002;346:235-242. [PubMed: 11807147]

Cunningham D, Humblet Y, et al. Cetuximab monotherapy and cetuximab plus irinotecan in irinotecanrefractory metastatic colorectal cancer. N Engl J Med 2004;351:337-345. [PubMed: 15269313]

Davies AM, Lara PN, Lau DH, Mack PC, Gumerlock PH, Gandara DR. Intermittent erlotinib in combination with docetaxel (DOC): phase I schedules designed to achieve pharmacodynamic separation. J Clin Oncol 2005;23(16s)abstract 7038

Discafani CM, Carroll ML, et al. Irreversible inhibition of epidermal growth factor receptor tyrosine kinase with in vivo activity by N-[4-[(3-bromophenyl)amino]-6-quinazolinyl]-2-butynamide (CL-387,785). Biochem Pharmacol 1999;57:917-925. [PubMed: 10086326]

Dittmann K, Mayer C, et al. Radiation-induced epidermal growth factor receptor nuclear import is linked to activation of DNA-dependent protein kinase. J Biol Chem 2005;280:31182-31189. [PubMed: 16000298]

Doherty L, Gigas DC, et al. Pilot study of the combination of EGFR and mTOR inhibitors in recurrent malignant gliomas. Neurology 2006;67:156-158. [PubMed: 16832099]

Dutu T, Michiels S, et al. Differential expression of biomarkers in lung adenocarcinoma: a comparative study between smokers and never-smokers. Ann Oncol 2005;16:1906-1914. [PubMed: 16219624]

Early Breast Cancer Trialists' Collaborative Group. Tamoxifen for early breast cancer: an overview of the randomised trials. Lancet 1998;351:1451-1467. [PubMed: 9605801]

Easton JB, Houghton PJ. Therapeutic potential of target of rapamycin inhibitors. Expert Opin Ther Targets 2004;8:551-564. [PubMed: 15584862]

Engelman JA, Zejnullahu K, et al. PF00299804, an irreversible pan-ERBB inhibitor, is effective in lung cancer models with EGFR and ERBB2 mutations that are resistant to gefitinib. Cancer Res 2007a; 67:11924-11932. [PubMed: 18089823]

Drug Dev Res. Author manuscript; available in PMC 2009 June 25. 
Engelman JA, Zejnullahu K, et al. MET amplification leads to gefitinib resistance in lung cancer by activating ERBB3 signaling. Science 2007b;316:1039-1043. [PubMed: 17463250]

Erlichman C, Hidalgo M, et al. Phase I study of EKB-569, an irreversible inhibitor of the epidermal growth factor receptor, in patients with advanced solid tumors. J Clin Oncol 2006;24:2252-2260. [PubMed: 16710023]

Fan QW, Knight ZA, et al. A dual PI3 kinase/mTOR inhibitor reveals emergent efficacy in glioma. Cancer Cell 2006;9:341-349. [PubMed: 16697955]

Friedmann B, Caplin M, et al. Modulation of DNA repair in vitro after treatment with chemotherapeutic agents by the epidermal growth factor receptor inhibitor gefitinib (ZD1839). Clin Cancer Res 2004;10:6476-6486. [PubMed: 15475435]

Fukuoka M, Yano S, et al. Multi-institutional randomized phase II trial of gefitinib for previously treated patients with advanced non-small-cell lung cancer (The IDEAL 1 Trial) [corrected]. J Clin Oncol 2003;21:2237-2246. [PubMed: 12748244]

Gandara DR, Davies AM, et al. Epidermal growth factor receptor inhibitors plus chemotherapy in nonsmall-cell lung cancer: biologic rationale for combination strategies. Clin Lung Cancer 2007;8(Suppl 2):S61-67. [PubMed: 17382026]

Gandara DR, Gumerlock PH. Epidermal growth factor receptor tyrosine kinase inhibitors plus chemotherapy: case closed or is the jury still out? J Clin Oncol 2005;23:5856-5858. [PubMed: 16043825]

Gatzemeier U, Pluzanska A, et al. Phase III study of erlotinib in combination with cisplatin and gemcitabine in advanced non-small-cell lung cancer: the Tarceva Lung Cancer Investigation Trial. J Clin Oncol 2007;25:1545-1552. [PubMed: 17442998]

Gatzemeier U, Rosell R, Ramlau R, Robinet G, Szczesna A, Quoix E, Font A, Jimenez E, Mueser M, Harstrick A. Cetuximab (C225) in combination with cisplatin/vinorelbine vs. cisplatin/vinorelbine alone int he first-line treatment of patients (pts) with epidermal growth factor receptor (EGFR) positive advanced non-small-cell lung cancer (NSCLC). Proc Am Soc Clin Oncol 2003;22abstract 2582

Giaccone G, Herbst RS, et al. Gefitinib in combination with gemcitabine and cisplatin in advanced nonsmall-cell lung cancer: a phase III trial-INTACT 1. J Clin Oncol 2004;22:777-784. [PubMed: 14990632]

Gibson S, Tu S, et al. Epidermal growth factor protects epithelial cells against Fas-induced apoptosis. Requirement for Akt activation. J Biol Chem 1999;274:17612-17618.

Gorre ME, Mohammed M, et al. Clinical resistance to STI-571 cancer therapy caused by BCR-ABL gene mutation or amplification. Science 2001;293:876-880. [PubMed: 11423618]

Greulich H, Chen TH, et al. Oncogenic transformation by inhibitor-sensitive and -resistant EGFR mutants. PLoS Med 2005;2:e313. [PubMed: 16187797]

Han SW, Kim TY, et al. Predictive and prognostic impact of epidermal growth factor receptor mutation in non-small-cell lung cancer patients treated with gefitinib. J Clin Oncol 2005;23:2493-2501. [PubMed: 15710947]

Han SW, Kim TY, et al. Optimization of patient selection for gefitinib in non-small cell lung cancer by combined analysis of epidermal growth factor receptor mutation, K-ras mutation, and Akt phosphorylation. Clin Cancer Res 2006;12:2538-2544. [PubMed: 16638863]

Haneda H, Sasaki H, et al. A correlation between EGFR gene mutation status and bronchioloalveolar carcinoma features in Japanese patients with adenocarcinoma. Jpn J Clin Oncol 2006;36:69-75. [PubMed: 16449241]

Hanna N, Lilenbaum R, et al. Phase II trial of cetuximab in patients with previously treated non-smallcell lung cancer. J Clin Oncol 2006;24:5253-5258. [PubMed: 17114658]

Harari PM, Allen GW, et al. Biology of interactions: antiepidermal growth factor receptor agents. J Clin Oncol 2007;25:4057-4065. [PubMed: 17827454]

Henschke CI, Yankelevitz DF, et al. Survival of patients with stage I lung cancer detected on CT screening. N Engl J Med 2006;355:1763-1771. [PubMed: 17065637]

Herbst RS, Giaccone G, et al. Gefitinib in combination with paclitaxel and carboplatin in advanced nonsmall-cell lung cancer: a phase III trial-INTACT 2. J Clin Oncol 2004;22:785-794. [PubMed: 14990633]

Drug Dev Res. Author manuscript; available in PMC 2009 June 25. 
Herbst RS, Johnson DH, et al. Phase I/II trial evaluating the anti-vascular endothelial growth factor monoclonal antibody bevacizumab in combination with the HER-1/epidermal growth factor receptor tyrosine kinase inhibitor erlotinib for patients with recurrent non-small-cell lung cancer. J Clin Oncol 2005;23:2544-2555. [PubMed: 15753462]

Herbst RS, Prager D, et al. TRIBUTE: a phase III trial of erlotinib hydrochloride (OSI-774) combined with carboplatin and paclitaxel chemotherapy in advanced non-small-cell lung cancer. J Clin Oncol 2005;23:5892-5899. [PubMed: 16043829]

Heymach JV, Johnson BE, et al. Randomized, placebo-controlled phase II study of vandetanib plus docetaxel in previously treated non small-cell lung cancer. J Clin Oncol 2007;25:4270-4277. [PubMed: 17878479]

Hirsch FR, Varella-Garcia M, et al. Epidermal growth factor receptor in non-small-cell lung carcinomas: correlation between gene copy number and protein expression and impact on prognosis. J Clin Oncol 2003;21:3798-3807. [PubMed: 12953099]

Hirsch FR, Varella-Garcia M, et al. Increased epidermal growth factor receptor gene copy number detected by fluorescence in situ hybridization associates with increased sensitivity to gefitinib in patients with bronchioloalveolar carcinoma subtypes: a Southwest Oncology Group Study. J Clin Oncol 2005;23:6838-6845. [PubMed: 15998906]

Hirsch FR, Varella-Garcia M, et al. Molecular predictors of outcome with gefitinib in a phase III placebocontrolled study in advanced non-small-cell lung cancer. J Clin Oncol 2006;24:5034-5042. [PubMed: 17075123]

Hirsch FR, Varella-Garcia M, et al. Combination of EGFR gene copy number and protein expression predicts outcome for advanced non-small-cell lung cancer patients treated with gefitinib. Ann Oncol 2007;18:752-760. [PubMed: 17317677]

Hurbin A, Dubrez L, et al. Inhibition of apoptosis by amphiregulin via an insulin-like growth factor-1 receptor-dependent pathway in non-small cell lung cancer cell lines. J Biol Chem 2002;277:4912749133. [PubMed: 12356750]

Husgafvel-Pursiainen K, Hackman P, et al. K-ras mutations in human adenocarcinoma of the lung: association with smoking and occupational exposure to asbestos. Int J Cancer 1993;53:250-256. [PubMed: 8425762]

Ihle NT, Paine-Murrieta G, et al. The phosphatidylinositol-3-kinase inhibitor PX-866 overcomes resistance to the epidermal growth factor receptor inhibitor gefitinib in A-549 human non-small cell lung cancer xenografts. Mol Cancer Ther 2005;4:1349-1357. [PubMed: 16170026]

Inoue A, Saijo Y, et al. Severe acute interstitial pneumonia and gefitinib. Lancet 2003;361:137-139. [PubMed: 12531582]

Inoue A, Suzuki T, et al. Prospective phase II study of gefitinib for chemotherapy-naive patients with advanced non-small-cell lung cancer with epidermal growth factor receptor gene mutations. J Clin Oncol 2006;24:3340-3346. [PubMed: 16785471]

Inukai M, Toyooka S, et al. Presence of epidermal growth factor receptor gene T790M mutation as a minor clone in non-small cell lung cancer. Cancer Res 2006;66:7854-7858. [PubMed: 16912157]

Janne PA, Gurubhagavatula S, et al. Outcomes of patients with advanced non-small cell lung cancer treated with gefitinib (ZD1839, Iressa) on an expanded access study. Lung Cancer 2004;44:221-230. [PubMed: 15084387]

Janne PA, Engelman JA, et al. Epidermal growth factor receptor mutations in non-small-cell lung cancer: implications for treatment and tumor biology. J Clin Oncol 2005;23:3227-3234. [PubMed: 15886310]

Johnson BE, Janne PA. Selecting patients for epidermal growth factor receptor inhibitor treatment: a FISH story or a tale of mutations? J Clin Oncol 2005;23:6813-6816. [PubMed: 16145056]

Jonker DJ, O'Callaghan CJ, et al. Cetuximab for the treatment of colorectal cancer. N Engl J Med. 2007;357:2040-2048.

Kantarjian H, Sawyers C, et al. Hematologic and cytogenetic responses to imatinib mesylate in chronic myelogenous leukemia. N Engl J Med 2002;346:645-552. [PubMed: 11870241]

Kelly K, Chansky K, et al. Phase III trial of maintenance gefitinib or placebo after concurrent chemoradiotherapy and docetaxel consolidation in inoperable stage III non-small-cell lung cancer: SWOG S0023. J Clin Oncol 2008;26:2450-2456. [PubMed: 18378568] 
Kelly K, Herbst RS, Crowley JJ, McCoy J, Atkins JN, Lara PN, Dakhil SR, Albain KS, Kim ES, Gandara DR. Concurrent chemotherapy plus cetuximab or chemotherapy followed by cetuximab in advanced non-small cell lung cancer (NSCLC): a randomized phase II selectional trial SWOG 0342. J Clin Oncol ASCO Annual Meeting Proc Part I 2006;24(18SSuppl):7015.

Khambata-Ford S, Garrett CR, et al. Expression of epiregulin and amphiregulin and K-ras mutation status predict disease control in metastatic colorectal cancer patients treated with cetuximab. J Clin Oncol 2007;25:3230-3237. [PubMed: 17664471]

Kim KS, Jeong JY, et al. Predictors of the response to gefitinib in refractory non-small cell lung cancer. Clin Cancer Res 2005;11:2244-2251. [PubMed: 15788673]

Kimura TM, Mahaffey CM, Pryde BJ, Mack PC, Davis AM, Gandara DR, Gumerlock PH. Apoptotic effects of the docetaxek->OSI-774 combination in non-small cell lung carcinoma (NSCLC) cells. J Clin Oncol 2004;22(14S)abstract 7143

Kobayashi S, Boggon TJ, et al. EGFR mutation and resistance of non-small-cell lung cancer to gefitinib. N Engl J Med 2005;352:786-792. [PubMed: 15728811]

Kosaka T, Yatabe Y, et al. Mutations of the epidermal growth factor receptor gene in lung cancer: biological and clinical implications. Cancer Res 2004;64:8919-8923. [PubMed: 15604253]

Krause DS, Van Etten RA. Tyrosine kinases as targets for cancer therapy. N Engl J Med 2005;353:172187. [PubMed: 16014887]

Kris MG, Natale RB, et al. Efficacy of gefitinib, an inhibitor of the epidermal growth factor receptor tyrosine kinase, in symptomatic patients with non-small cell lung cancer: a randomized trial. JAMA 2003;290:2149-2158. [PubMed: 14570950]

Kwak EL, Sordella R, et al. Irreversible inhibitors of the EGF receptor may circumvent acquired resistance to gefitinib. Proc Natl Acad Sci USA 2005;102:7665-7670. [PubMed: 15897464]

Lilenbaum RC. The evolving role of cetuximab in non-small cell lung cancer. Clin Cancer Res 2006;12 (Pt 2):4432s-4435s. [PubMed: 16857823]

Lin SY, Makino K, et al. Nuclear localization of EGF receptor and its potential new role as a transcription factor. Nat Cell Biol 2001;3:802-808. [PubMed: 11533659]

Lynch TJ. 12th World Conference on Lung Cancer. 2007Abstract B303

Lynch TJ, Bell DW, et al. Activating mutations in the epidermal growth factor receptor underlying responsiveness of non-small-cell lung cancer to gefitinib. N Engl J Med 2004;350:2129-2139. [PubMed: 15118073]

Marchetti A, Martella C, et al. EGFR mutations in non-small-cell lung cancer: analysis of a large series of cases and development of a rapid and sensitive method for diagnostic screening with potential implications on pharmacologic treatment. J Clin Oncol 2005;23:857-865. [PubMed: 15681531]

Massarelli E, Andre F, et al. A retrospective analysis of the outcome of patients who have received two prior chemotherapy regimens including platinum and docetaxel for recurrent non-small-cell lung cancer. Lung Cancer 2003;39:55-61. [PubMed: 12499095]

Mendelsohn J. Epidermal growth factor receptor inhibition by a monoclonal antibody as anticancer therapy. Clin Cancer Res 1997;3(Pt 2):2703-2707. [PubMed: 10068277]

Mendelsohn J, Fan Z. Epidermal growth factor receptor family and chemosensitization. J Natl Cancer Inst 1997;89:341-343. [PubMed: 9060954]

Miller VA, Riely GJ, et al. Molecular characteristics of bronchioloalveolar carcinoma and adenocarcinoma, bronchioloalveolar carcinoma subtype, predict response to erlotinib. J Clin Oncol 2008;26:1472-1478. [PubMed: 18349398]

Mitsudomi T, Steinberg SM, et al. Ras gene mutations in non-small cell lung cancers are associated with shortened survival irrespective of treatment intent. Cancer Res 1991;51:4999-5002. [PubMed: 1654209]

Mitsudomi T, Kosaka T, et al. Mutations of the epidermal growth factor receptor gene predict prolonged survival after gefitinib treatment in patients with non-small-cell lung cancer with postoperative recurrence. J Clin Oncol 2005;23:2513-5220. [PubMed: 15738541]

Moore MJ, Goldstein D, et al. Erlotinib plus gemcitabine compared with gemcitabine alone in patients with advanced pancreatic cancer: a phase III trial of the National Cancer Institute of Canada Clinical Trials Group. J Clin Oncol 2007;25:1960-1966. [PubMed: 17452677]

Drug Dev Res. Author manuscript; available in PMC 2009 June 25. 
Moroni M, Veronese S, et al. Gene copy number for epidermal growth factor receptor (EGFR) and clinical response to antiEGFR treatment in colorectal cancer: a cohort study. Lancet Oncol 2005;6:279-286. [PubMed: 15863375]

Mukohara T, Engelman JA, et al. Differential effects of gefitinib and cetuximab on non-small-cell lung cancers bearing epidermal growth factor receptor mutations. J Natl Cancer Inst 2005;97:1185-1194. [PubMed: 16106023]

Nicholson RI, Gee JM, et al. EGFR and cancer prognosis. Eur J Cancer 2001;37(Suppl 4):S9-15. [PubMed: 11597399]

Nyati MK, Morgan MA, et al. Integration of EGFR inhibitors with radiochemotherapy. Nat Rev Cancer 2006;6:876-885. [PubMed: 17036041]

Ohsaki Y, Tanno S, et al. Epidermal growth factor receptor expression correlates with poor prognosis in non-small cell lung cancer patients with p53 overexpression. Oncol Rep 2000;7:603-607. [PubMed: 10767376]

Oc P, Modjtahedi H, et al. Epidermal growth factor-like ligands differentially up-regulate matrix metalloproteinase 9 in head and neck squamous carcinoma cells. Cancer Res 2000;60:1121-1128. [PubMed: 10706134]

Paez JG, Janne PA, et al. EGFR mutations in lung cancer: correlation with clinical response to gefitinib therapy. Science 2004;304:1497-1500. [PubMed: 15118125]

Pao W, Miller V, et al. EGF receptor gene mutations are common in lung cancers from never smokers and are associated with sensitivity of tumors to gefitinib and erlotinib. Proc Natl Acad Sci USA 2004;101:13306-13311. [PubMed: 15329413]

Pao W, Miller VA, et al. Acquired resistance of lung adenocarcinomas to gefitinib or erlotinib is associated with a second mutation in the EGFR kinase domain. PLoS Med 2005a;2:e73. [PubMed: 15737014]

Pao W, Wang TY, et al. KRAS mutations and primary resistance of lung adenocarcinomas to gefitinib or erlotinib. PLoS Med 2005b;2:e17. [PubMed: 15696205]

Paz-Ares LS, Sanchez JM, Garcia-Velasco A, Massuti B, Lopez-Vivanco G, Provencio M, Montes A, Isla D, Amador ML, Rosell R. A prospective phase II trial of erlotinib in advanced non-small-cell lung cancer (NSCLC) patients (p) with mutations in the tyrosine kinase (TK) domain of the epidermal growth factor receptor (EGFR). J Clin Oncol 2006;24(18S)abstract 7020

Perez-Soler R, Chachoua A, et al. Determinants of tumor response and survival with erlotinib in patients with non—small-cell lung cancer. J Clin Oncol 2004;22:3238-3247. [PubMed: 15310767]

Petit AM, Rak J, et al. Neutralizing antibodies against epidermal growth factor and ErbB-2/neu receptor tyrosine kinases down-regulate vascular endothelial growth factor production by tumor cells in vitro and in vivo: angiogenic implications for signal transduction therapy of solid tumors. Am J Pathol 1997;151:1523-1530. [PubMed: 9403702]

Pirker R, Szczesna A, von Pawl J, Krzakowski M, Ramlau R, Park K, Gatzemeier U, Bajeta E, Emig M, Pereira JR. FLEX: a randomized, multicenter, phase III study of cetuximab in combination with cisplatin/vinorelbine $(\mathrm{CV})$ versus $\mathrm{CV}$ alone in the first-line treatment of patients with advanced non-small cell lung cancer (NSCLC). J Clin Oncol 2008;26abstract 3

Prenzel N, Fischer OM, et al. The epidermal growth factor receptor family as a central element for cellular signal transduction and diversification. Endocr Relat Cancer 2001;8:11-31. [PubMed: 11350724]

Prewett M, Rockwell P, et al. The biologic effects of C225, a chimeric monoclonal antibody to the EGFR, on human prostate carcinoma. J Immunother Emphasis Tumor Immunol 1996;19:419-427. [PubMed: 9041461]

Raez LE, Lopes G, et al. Clinical responses to gefinitib after failure of treatment with cetuximab in advanced non-small-cell lung cancer. J Clin Oncol 2005;23:4244-4245. [PubMed: 15961783]

Robert F, Blumenschein G, et al. Phase I/IIa study of cetuximab with gemcitabine plus carboplatin in patients with chemotherapy-naive advanced non-small-cell lung cancer. J Clin Oncol 2005;23:9089-9096. [PubMed: 16301597]

Rodenhuis S, van de Wetering ML, et al. Mutational activation of the K-ras oncogene. A possible pathogenetic factor in adenocarcinoma of the lung. N Engl J Med 1987;317:929-935. 
Rosell R, Robinet G, et al. Randomized phase II study of cetuximab plus cisplatin/vinorelbine compared with cisplatin/vinorelbine alone as first-line therapy in EGFR-expressing advanced non-small-cell lung cancer. Ann Oncol 2008;19:362-369. [PubMed: 17947225]

Rubin BP, Duensing A. Mechanisms of resistance to small molecule kinase inhibition in the treatment of solid tumors. Lab Invest 2006;86:981-986. [PubMed: 16924245]

Rubin Grandis J, Melhem MF, et al. Levels of TGF-alpha and EGFR protein in head and neck squamous cell carcinoma and patient survival. J Natl Cancer Inst 1998;90:824-832. [PubMed: 9625170]

Rusch V, Baselga J, et al. Differential expression of the epidermal growth factor receptor and its ligands in primary non-small cell lung cancers and adjacent benign lung. Cancer Res 1993;53(Suppl):2379_ 2385. [PubMed: 7683573]

Salomon DS, Brandt R, et al. Epidermal growth factor-related peptides and their receptors in human malignancies. Crit Rev Oncol Hematol 1995;19:183-232. [PubMed: 7612182]

Saltz LB, Meropol NJ, et al. Phase II trial of cetuximab in patients with refractory colorectal cancer that expresses the epidermal growth factor receptor. J Clin Oncol 2004;22:1201-1208. [PubMed: 14993230]

Schiller JH, Harrington D, et al. Comparison of four chemotherapy regimens for advanced non-smallcell lung cancer. N Engl J Med 2002;346:92-98. [PubMed: 11784875]

Schreiber AB, Winkler ME, et al. Transforming growth factor-alpha: a more potent angiogenic mediator than epidermal growth factor. Science 1986;232:1250-1253. [PubMed: 2422759]

Sequist LV. Second-generation epidermal growth factor receptor tyrosine kinase inhibitors in non-small cell lung cancer. Oncologist 2007;12:325-330. [PubMed: 17405897]

Sequist LV, Bell DW, et al. Molecular predictors of response to epidermal growth factor receptor antagonists in non-small-cell lung cancer. J Clin Oncol 2007;25:587-595. [PubMed: 17290067]

Sequist LV, Lynch TJ. EGFR tyrosine kinase inhibitors in lung cancer: an evolving story. Annu Rev Med 2008;59:429-442. [PubMed: 17716025]

Sequist LV, Martins RG, et al. First-line gefitinib in patients with advanced non-small-cell lung cancer harboring somatic EGFR mutations. J Clin Oncol 2008;26:2442-2449. [PubMed: 18458038]

Sharma SV, Bell DW, et al. Epidermal growth factor receptor mutations in lung cancer. Nat Rev Cancer 2007;7:169-181. [PubMed: 17318210]

Shepherd FA, Dancey J, et al. Prospective randomized trial of docetaxel versus best supportive care in patients with non-small-cell lung cancer previously treated with platinum-based chemotherapy. J Clin Oncol 2000;18:2095-2103. [PubMed: 10811675]

Shepherd FA, Rodrigues Pereira J, et al. Erlotinib in previously treated non-small-cell lung cancer. N Engl J Med 2005;353:123-132. [PubMed: 16014882]

Shibuya K, Komaki R, et al. Targeted therapy against VEGFR and EGFR with ZD6474 enhances the therapeutic efficacy of irradiation in an orthotopic model of human non-small-cell lung cancer. Int J Radiat Oncol Biol Phys 2007;69:1534-1543. [PubMed: 17889445]

Shigematsu H, Lin L, et al. Clinical and biological features associated with epidermal growth factor receptor gene mutations in lung cancers. J Natl Cancer Inst 2005;97:339-346. [PubMed: 15741570]

Sirotnak FM, Zakowski MF, et al. Efficacy of cytotoxic agents against human tumor xenografts is markedly enhanced by coadministration of ZD1839 (Iressa), an inhibitor of EGFR tyrosine kinase. Clin Cancer Res 2000;6:4885-4892. [PubMed: 11156248]

Smaill JB, Rewcastle GW, et al. Tyrosine kinase inhibitors. 17. Irreversible inhibitors of the epidermal growth factor receptor: 4-(phenylamino)quinazoline- and 4-(phenylamino)pyrido[3,2-d] pyrimidine-6-acrylamides bearing additional solubilizing functions. J Med Chem 2000;43:1380 1397. [PubMed: 10753475]

Sumitomo M, Asano T, et al. ZD1839 modulates paclitaxel response in renal cancer by blocking paclitaxel-induced activation of the epidermal growth factor receptor-extracellular signal-regulated kinase pathway. Clin Cancer Res 2004;10:794-801. [PubMed: 14760103]

Tabernero J. The role of VEGF and EGFR inhibition: implications for combining anti-VEGF and antiEGFR agents. Mol Cancer Res 2007;5:203-220. [PubMed: 17374728]

Takano T, Ohe Y, et al. Epidermal growth factor receptor gene mutations and increased copy numbers predict gefitinib sensitivity in patients with recurrent non-small-cell lung cancer. J Clin Oncol 2005;23:6829-6837. [PubMed: 15998907] 
Thatcher N, Chang A, et al. Gefitinib plus best supportive care in previously treated patients with refractory advanced non-small-cell lung cancer: results from a randomised, placebo-controlled, multicentre study (Iressa Survival Evaluation in Lung Cancer). Lancet 2005;366:1527-1537. [PubMed: 16257339]

Thienelt CD, Bunn PA Jr, et al. Multicenter phase I/II study of cetuximab with paclitaxel and carboplatin in untreated patients with stage IV non-small-cell lung cancer. J Clin Oncol 2005;23:8786-8793. [PubMed: 16246975]

Tsao MS, Sakurada A, et al. Erlotinib in lung cancer - molecular and clinical predictors of outcome. N Engl J Med 2005;353:133-144. [PubMed: 16014883]

Van Cutsem E, Peeters M, et al. Open-label phase III trial of panitumumab plus best supportive care compared with best supportive care alone in patients with chemotherapy-refractory metastatic colorectal cancer. J Clin Oncol 2007;25:1658-1664. [PubMed: 17470858]

Veronese ML, Algazy K, et al. Gefitinib in patients with advanced non-small cell lung cancer (NSCLC): the expanded access protocol experience at the University of Pennsylvania. Cancer Invest 2005;23:296-302. [PubMed: 16100941]

Wacker B, Nagrani T, et al. Correlation between development of rash and efficacy in patients treated with the epidermal growth factor receptor tyrosine kinase inhibitor erlotinib in two large phase III studies. Clin Cancer Res 2007;13:3913-3921. [PubMed: 17606725]

Weinstein IB. Cancer. Addiction to oncogenes—the Achilles heal of cancer. Science 2002;297:63-64.

Weinstein IB, Joe AK. Mechanisms of disease: oncogene addiction-a rationale for molecular targeting in cancer therapy. Nat Clin Pract Oncol 2006;3:448-457. [PubMed: 16894390]

Yang $\mathrm{CH}$, Yu CJ, et al. Specific EGFR mutations predict treatment outcome of stage IIIB/IV patients with chemotherapy-naive non-small-cell lung cancer receiving first-line gefitinib monotherapy. $\mathrm{J}$ Clin Oncol 2008;26:2745-2753. [PubMed: 18509184]

Yun CH, Boggon TJ, et al. Structures of lung cancer-derived EGFR mutants and inhibitor complexes: mechanism of activation and insights into differential inhibitor sensitivity. Cancer Cell 2007;11:217-227. [PubMed: 17349580]

Zhang W, Gordon M, et al. Cyclin D1 and epidermal growth factor polymorphisms associated with survival in patients with advanced colorectal cancer treated with Cetuximab. Pharmacogenet Genomics 2006;16:475-483. [PubMed: 16788380]

Zhang W, Gordon M, et al. FCGR2A and FCGR3A polymorphisms associated with clinical outcome of epidermal growth factor receptor expressing metastatic colorectal cancer patients treated with single-agent cetuximab. J Clin Oncol 2007;25:3712-3718. [PubMed: 17704420]

Drug Dev Res. Author manuscript; available in PMC 2009 June 25. 


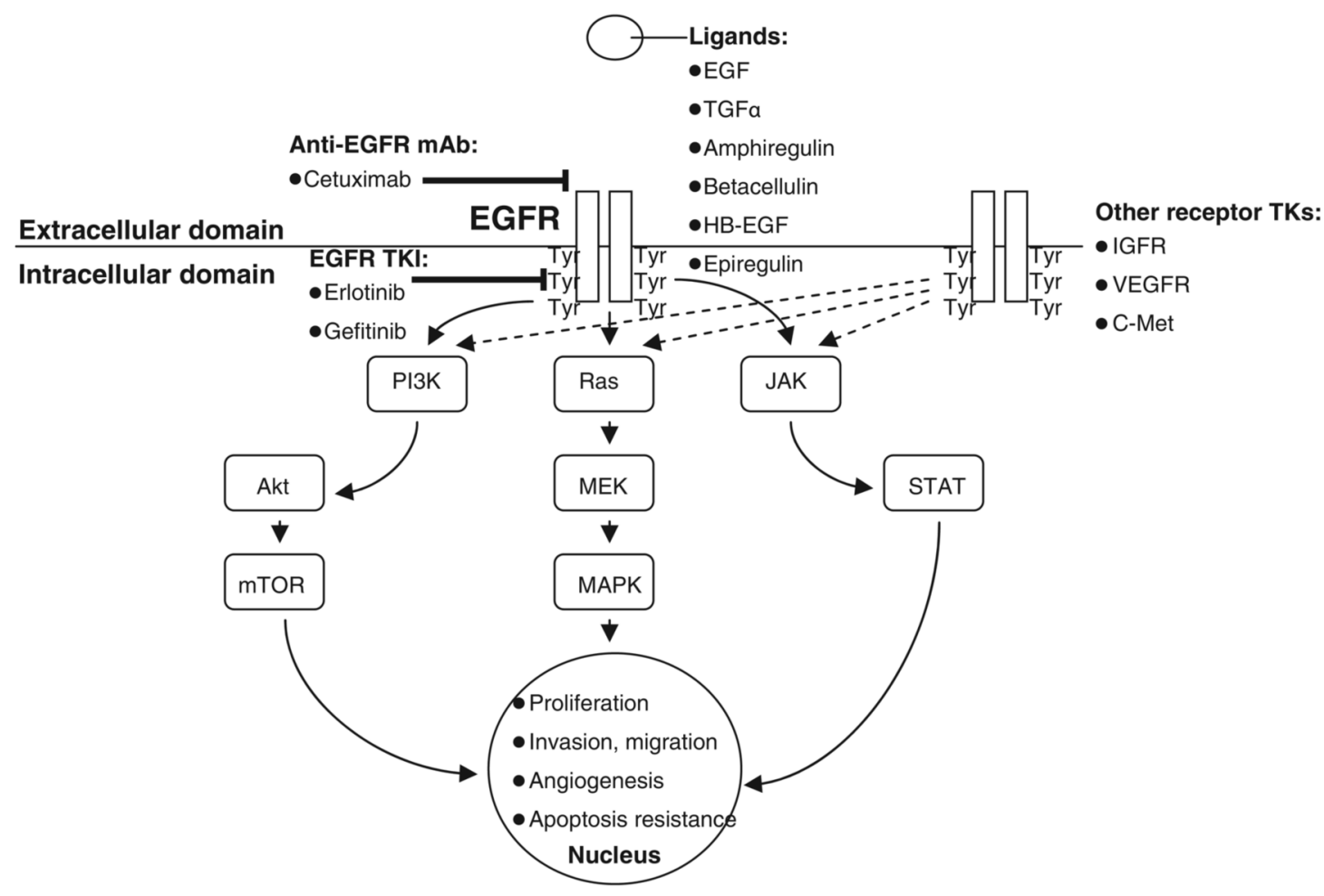

Fig. 1.

EGFR signaling, actions, and inhibition in NSCLC. Dashed lines indicate redundant molecular signaling pathways potentially causing resistance to EGFR inhibition. Abbreviations: EGF, epidermal growth factor; HB-EGF, heparin-bound EGF; IGFR, insulin-like growth factor receptor; JAK, Janus kinase; MAPK, mitogen-activated protein kinase; MEK, MAPK/ extracellular signal-regulated kinase kinase; mTOR, mammalian target of rapamycin; PI3K, phosphatidylinositol-3 kinase; STAT, signal transducer and activator of transcription; TGF$\alpha$, transforming growth factor- $\alpha$; TK, tyrosine kinase; TKI, tyrosine kinase inhibitor; Tyr, tyrosine; VEGFR, vascular endothelial growth factor receptor. 
TABLE 1

Features of EGFR-Inhibiting Drugs for the Treatment of NSCLC: Tyrosine Kinase Inhibitors (TKIs) and Monoclonal Antibodies (mAbs)

\begin{tabular}{lll}
\hline & $\begin{array}{l}\text { Tyrosine kinase } \\
\text { inhibitors (TKIs) }\end{array}$ & Monoclonal antibodies (mAbs) \\
\hline $\begin{array}{lll}\text { Examples in } \\
\text { NSCLC }\end{array}$ & $\begin{array}{l}\text { Erlotinib } \\
\text { (Tarceva) }\end{array}$ & Cetuximab (Erbitux) \\
Gefitinib (Iressa) & \\
Site of action & Intracellular & Extracellular \\
Mechanism(s) & $\begin{array}{l}\text { Inhibition of } \\
\text { tyrosine } \\
\text { kinase } \\
\text { function }\end{array}$ & $\begin{array}{l}\text { Antagonism of ligand-receptor } \\
\text { binding; internalization }\end{array}$ \\
& $\begin{array}{l}\text { Internalization, degradation } \\
\text { of EGFR; recruitment of host }\end{array}$ \\
immune functions (e.g., \\
ADCC)
\end{tabular}

ADCC, antibody-dependent cellular cytotoxicity; CYP-450, cyto-chrome P-450; NSCLC, non small cell lung cancer; EGFR, epidermal growth factor receptor. 
TABLE 2

Comparison of Phase III Clinical Trials of Single-Agent EGFR TKI Therapy in Recurrent/Refractory Advanced NSCLC

\begin{tabular}{lll}
\hline & Gefitinib & Erlotinib \\
\hline $\begin{array}{l}\text { Phase III } \\
\text { clinical trial }\end{array}$ & $\begin{array}{l}\text { ISEL (Iressa Survival } \\
\text { Evaluation in } \\
\text { Lung Cancer) }\end{array}$ & NCIC BR21 \\
Study & $\begin{array}{l}\text { Early relapse/ } \\
\text { progression } \\
\text { (within } 90 \text { days) } \\
\text { after prior } \\
\text { platinum } \\
\text { chemotherapy }\end{array}$ & $\begin{array}{l}\text { Relapse/ } \\
\text { progression } \\
\text { (no time limit } \\
\text { specified) } \\
\text { after prior platinum } \\
\text { chemotherapy }\end{array}$ \\
& 5 nmol/L & 2 mnol/L \\
Affinity for & $700 \mathrm{mg}$ & $150 \mathrm{mg}$ \\
EGFR (IC ${ }_{50}$ ) & $250 \mathrm{mg}$ & $150 \mathrm{mg}$ \\
Maximum & $37 \%$ & $76 \%$ \\
tolerated dose & $27 \%$ & $55 \%$ \\
Dose selected for trial & & \\
Frequency of rash & & \\
Frequency of diarrhea & & \\
\hline
\end{tabular}

Data from Blackhall et al. [2006] and Sharma et al. [2007]. 


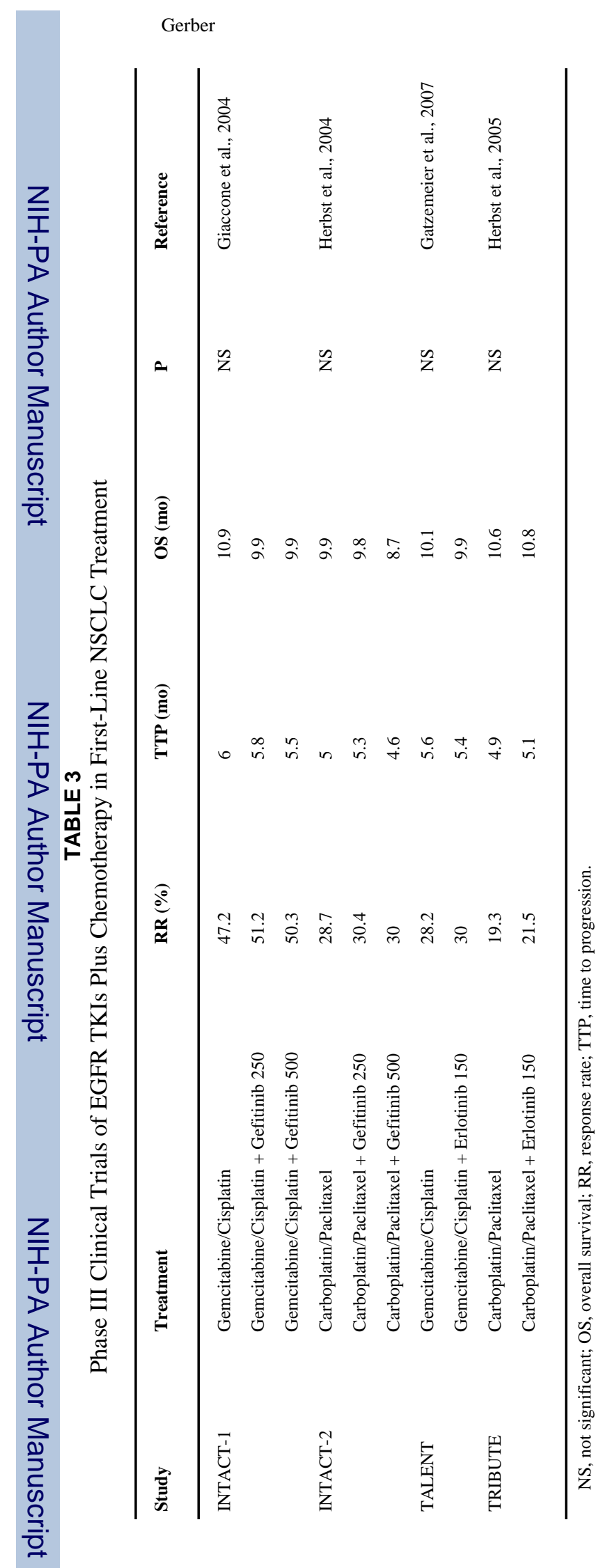

Drug Dev Res. Author manuscript; available in PMC 2009 June 25. 


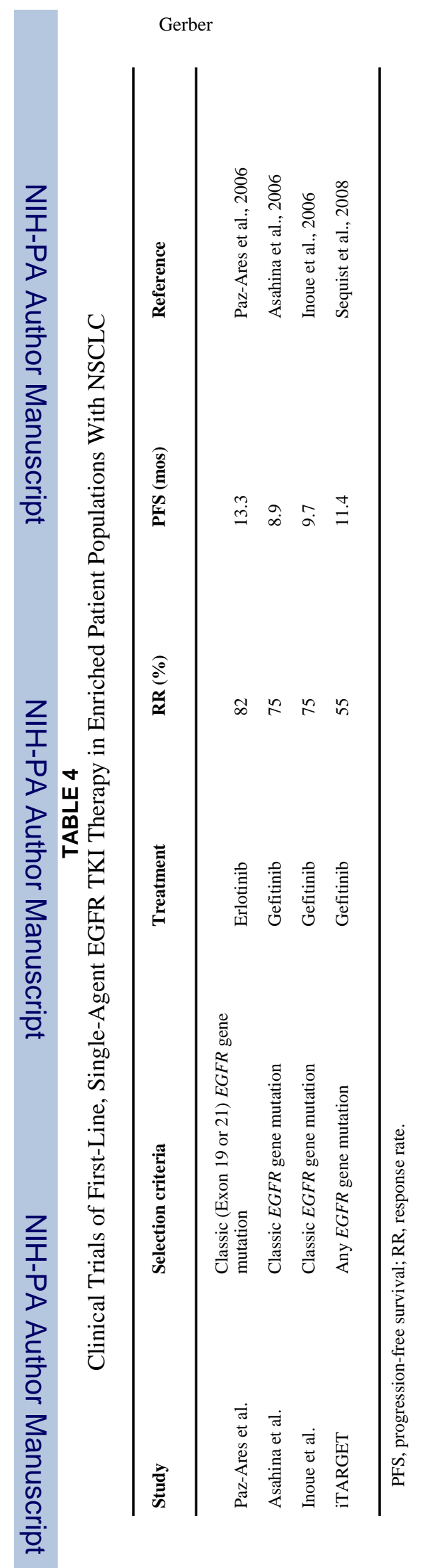

Page 22

Drug Dev Res. Author manuscript; available in PMC 2009 June 25. 


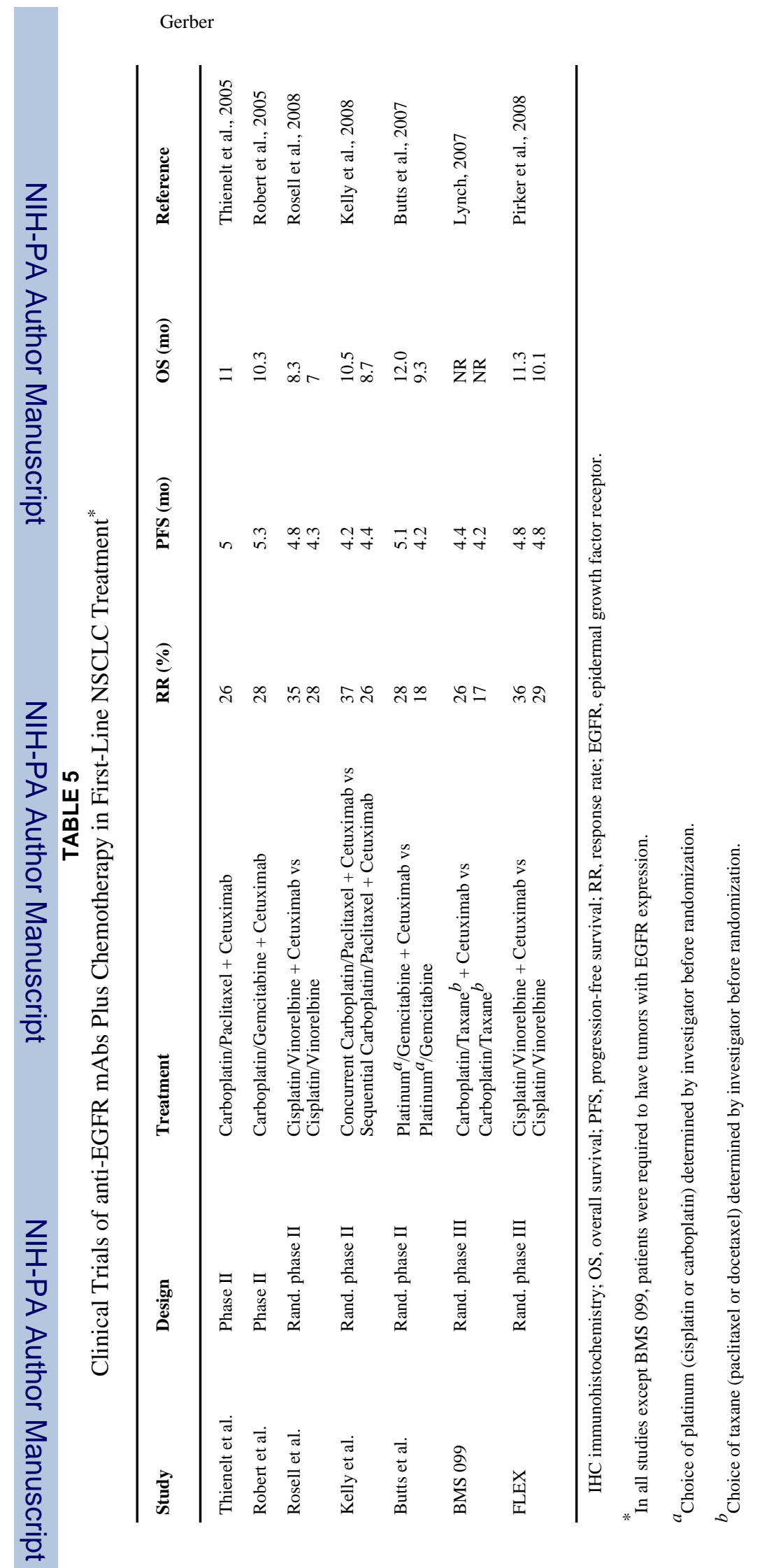

Drug Dev Res. Author manuscript; available in PMC 2009 June 25. 